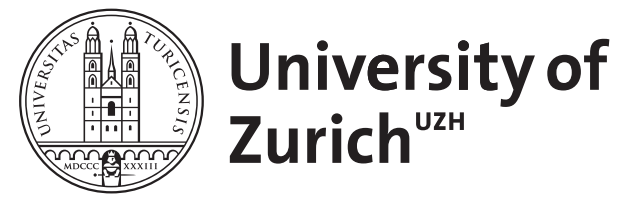

Zurich Open Repository and Archive

University of Zurich

University Library

Strickhofstrasse 39

CH-8057 Zurich

www.zora.uzh.ch

Year: 1965

\title{
Aging Changes and Osteoarthrosis in Castrate Mice Receiving Progesterone
}

Silberberg, R ; Silberberg, M

DOI: https://doi.org/10.1093/geronj/20.2.228

Posted at the Zurich Open Repository and Archive, University of Zurich

ZORA URL: https://doi.org/10.5167/uzh-154802

Journal Article

Published Version

Originally published at:

Silberberg, R; Silberberg, M (1965). Aging Changes and Osteoarthrosis in Castrate Mice Receiving Progesterone. Journal of Gerontology, 20(2):228-232.

DOI: https://doi.org/10.1093/geronj/20.2.228 


\title{
Aging Changes and Osteoarthrosis in Castrate Mice Receiving Progesterone
}

\author{
Ruth Silberberg, M.D. and Martin Silberberg, M.D. ${ }^{2}$
}

$\mathrm{T}$ IEStosterone and nortestosterone given to growing mice (Silberberg \& Silberberg, 1956, 1961; Howard, 1963) rats (Joss, Zuppinger, \& Sobel, 1963; Rönning, Mäkinen, Lathimer, \& Raijola, 1964), and children (Geller, 1964) advanced skeletal maturation. These compounds also accelerated the articular aging changes which may be considered as pacemakers for the evolution of senile osteoarthrosis (Weichselbaum, 1877; Silberberg \& Silberberg, 1941, 1956, 1961a,b; Bennett, Waine, \& Bauer, 1942; de Palma, 1957; Papadia, Montinari, \& Cagnazzo, 1959). Correspondingly, castration performed early in life retarded skeletal development in rats (Buffett \& Wyman, 1956) and mice (Silberberg \& Silberberg, 1956, 1961a). Orchiectomy also delayed articular aging and attenuated degenerative joint disease in mice of several strains (Silberberg, Thomasson, \& Silberberg, 1958; Silberberg \& Silberberg 1961a). The retardation of the sequelae of endochondral ossification observed subsequent to orchiectomy was partly counteracted by injections of progesterone (Silberberg \& Silberberg, 1965). In continuation of the latter investigations the effect of prolonged administration of progesterone on aged articular cartilage was studied in mice orchiectomized early in life.

\section{Material and Methods}

Twenty-four mice of strain C57BL Jax6, born in our laboratory were orchiectomized at the age of two or three weeks and received a subcutaneous injection of $250 \mu \mathrm{g}$ progesterone ${ }^{3}$ dissolved in $.05 \mathrm{ml}$. sesame oil once weekly

\footnotetext{
1 The investigation was supported by Grant A-00022 (C14) from the National Institute of Arthritis and Metabolic Diseases, National Institute of Health, Public Hcalth Service.

2 Department of Pathology, Washington University, School of Medicine, Saint Louis, Missouri, and Histopathological Institute of the University of Zürich, Zürich, Switzerland.

3 The crystalline substance used in this study was generously supplied by the Schering Corporation, Bloomfield, New Jersey.
}

from the age of four weeks. The animals were kept on a stock diet of Purina Laboratory Chow and water ad libitum. Weights were taken twice every month. The treatment was continued to 18 months of age, at which time the animals were killed. Complete necropsies were performed; the knee joints were removed as a whole and prepared for microscopic examination. The results were compared with those obtained in two control groups reported previously: (a) 30 untreated males of the same strain and age (Silberberg \& Silberberg, 1961b); (b) 29 non-injected orchiectomized mice. Animals of group (b) represented those of a series of 53 animals which were killed or died before the age of 18 months (Silberberg et al., 1958). The significance of the findings was analyzed by the $\chi^{2}$ test. Yates' correction for continuity ${ }^{4}$ (Mainland, 1963) was applied.

\section{Results}

The animals tolerated the treatment well, and only a few died or had to be killed prematurely. At the termination of the experiment the mean weight of the castrates which received progesterone was $27 \mathrm{Gm}$. (range 24-30 Gm.) as compared with $32 \mathrm{Gm}$. (range 29-35 Gm.) for untreated and to $24 \mathrm{Gm}$. (range 21-29 Gm.) for non-injected orchiectomized animals of the same age. All injected mice showed subcutaneous oil cysts and some fibrosis at the sites of injections; no lesions of pathological significance were noted.

The microscopic findings were graded as follows: (1) unchanged joints showing smooth surfaces and regular stratification of chondrocytes with gradual transition from small spin-

\footnotetext{
4 The forniula used,$$
\chi^{2}=\frac{\left([a d-b c]-\frac{N}{2}\right)^{2} \bullet N}{(a+b) \bullet(c+d) \bullet(a+c) \bullet(b+d)}
$$

where $a$ and $b$ represent the number of arthrosis-positive or -negative non-injected castrate mice, $c$ and $d$ the number of arthrosis-positive or -negative castrate mice receiving progesterone, and $\mathrm{N}$ the combined number of non-injected and injected castrate mice.
} 


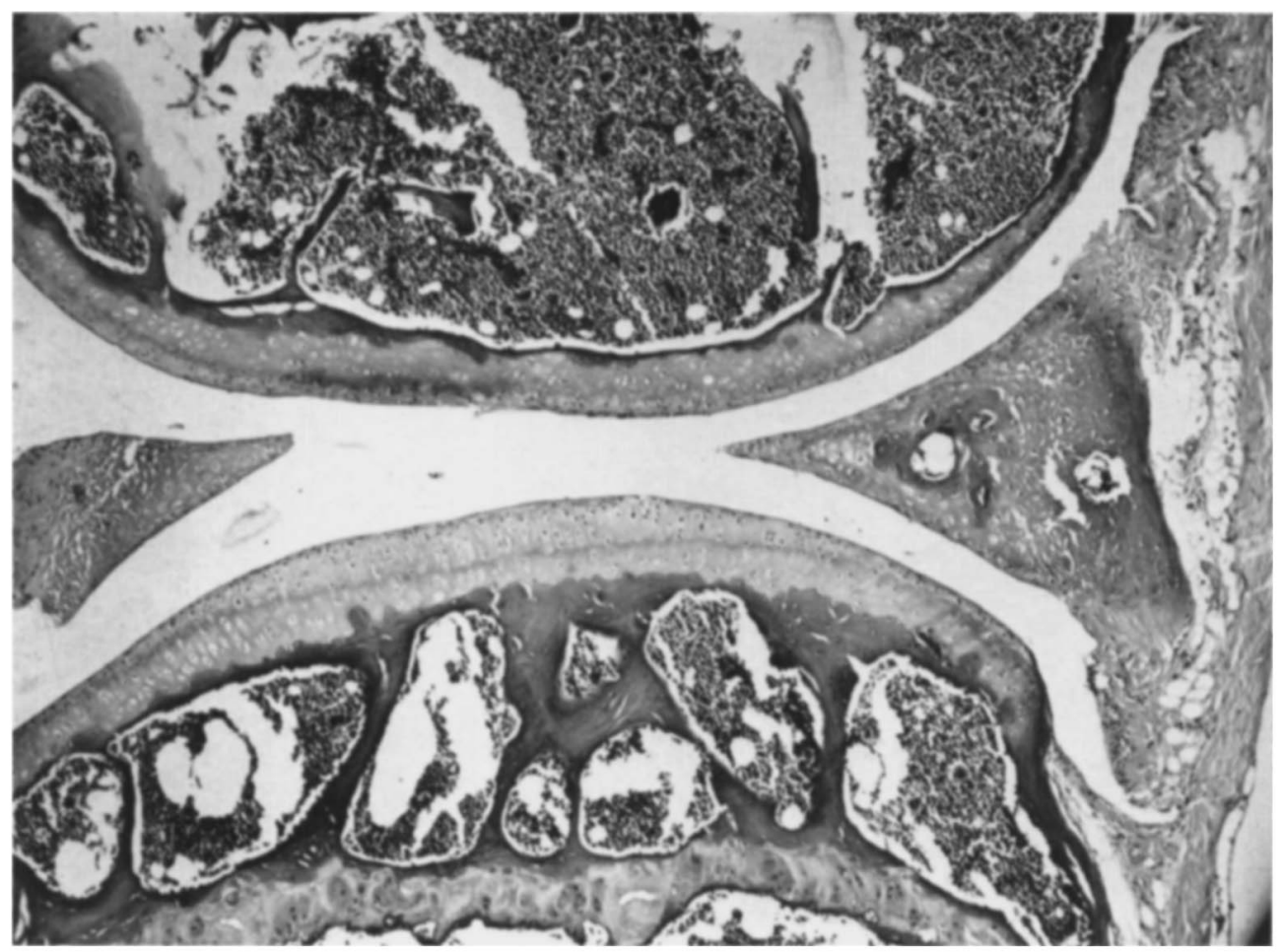

Fig. 1. Unchanged knee joint showing intact surfaces of femur (top), tibia (bottom), and menisci (middle right and left). $\times 70$.

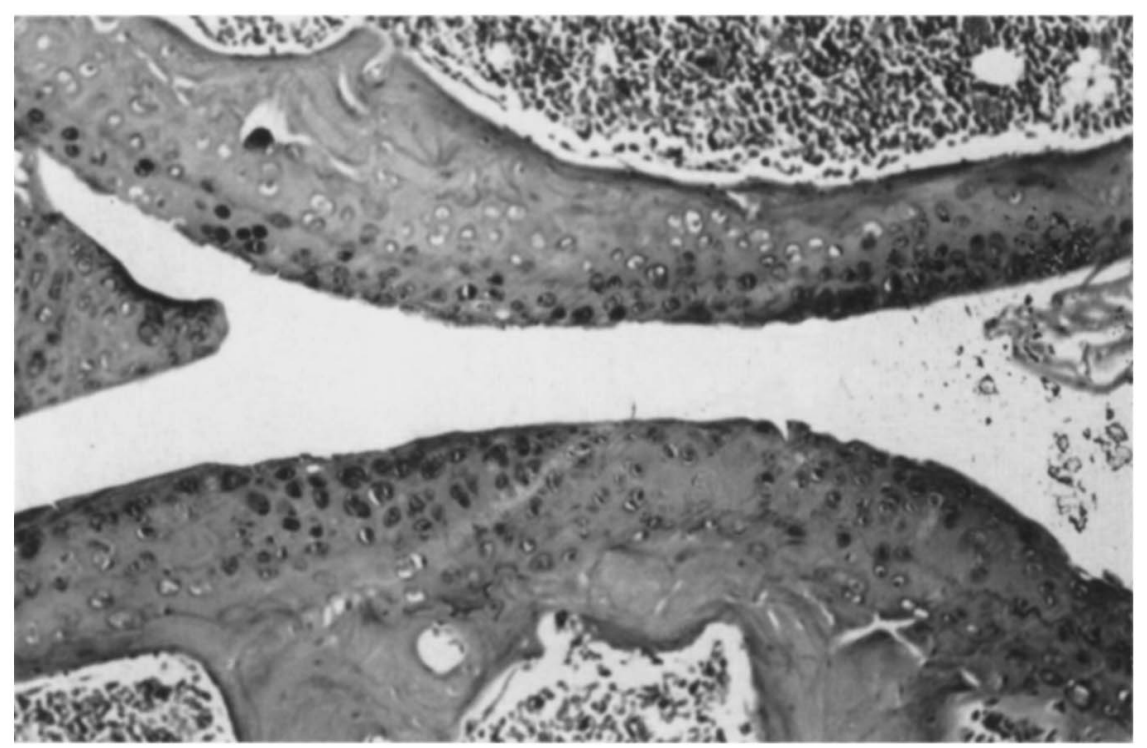

Fig. 2. Aging changes: Diffuse hypertrophy and hyperplasia of chondrocytes at both femur (top) and tibia (bottom) with small foci of degeneration and roughening of the surfaces. x140. 
dle-shaped types near the surface to large hypertrophic cells adjoining the bone (Fig. 1); (2) old age changes represented by hyperplasia and hypertrophy of chondrocytes associated with or followed by fading and degeneration of cells and intact or slightly roughened or frayed surface (Fig. 2); (3) osteoarthrosis characterized by superficial erosions or deep ulcerations of the surface, fibrosis, and cyst formation of the epiphyseal bone marrow, outgrowth of cartilage and marginal bony spurs, proliferation of synovialis, calcification and cartilagination of ligaments, a combination of changes leading to deformities of the joint cavity (Fig. 3).

Osteoarthrotic lesions were classified as slight or advanced, depending on the presence of superficial erosions or deep ulcerations and the presence or absence of joint deformities, respectively.

The findings are summarized in Table 1.

The mean age at death of 24 castrates treated with progesterone was 17.8 months.
Two mice $(8 \%)$ had intact articulations. Old age changes were found in 14 mice $(58 \%)$, and osteoarthrosis was present in 8 animals $(34 \%)$. Four of these lesions were severe. The difference between the incidences of osteoarthrosis in non-injected and injected castrates was highly significant $(P>0.01)$.

Table 1. Microscopic Findings in the Knee Joints of Non-Treated Mice, of Castrated Mice and of Castrated Mice Treated with Progesterone.

\begin{tabular}{|c|c|c|c|c|c|c|c|c|}
\hline \multirow[b]{3}{*}{ Experiment } & \multirow{3}{*}{$\begin{array}{c}\text { No. of } \\
\text { Mice }\end{array}$} & \multirow{3}{*}{$\begin{array}{c}\text { Mean Age } \\
\text { at } \\
\text { Death } \\
\text { (Mo.) }\end{array}$} & \multicolumn{6}{|c|}{ Conditions in the Knee Joint } \\
\hline & & & \multicolumn{2}{|c|}{$\begin{array}{c}\text { No } \\
\text { Change }\end{array}$} & \multicolumn{2}{|c|}{$\begin{array}{l}\text { Old Age } \\
\text { Changes }\end{array}$} & \multicolumn{2}{|c|}{$\begin{array}{l}\text { Osteo- } \\
\text { arthrosis }\end{array}$} \\
\hline & & & No. & $\%$ & No. & $\%$ & No. & $\%$ \\
\hline $\begin{array}{l}\text { Untreated } \\
\text { Controls (5) }\end{array}$ & $30^{\mathrm{a}}$ & 18.0 & 6 & 20 & 16 & 53 & 8 & 27 \\
\hline $\begin{array}{l}\text { Castrate } \\
\text { Controls (5) }\end{array}$ & $29^{\mathrm{a}}$ & 17.5 & 12 & 41 & 16 & 55 & $1^{*}$ & 4 \\
\hline $\begin{array}{l}\text { Castrates + } \\
\text { Progestrone }\end{array}$ & 24 & 17.8 & 2 & 8 & 14 & 58 & $8^{*}$ & 34 \\
\hline
\end{tabular}

*Significance of difference between the incidence of osteoarthrosis in noninjected and in injected castrates, respectively: $\chi^{2}=6.371(P>0.01)$.

: Findings reported previously (Silberberg, Thomasson, \& Silberberg, 1958; Silberberg \& Silberberg, 1961).

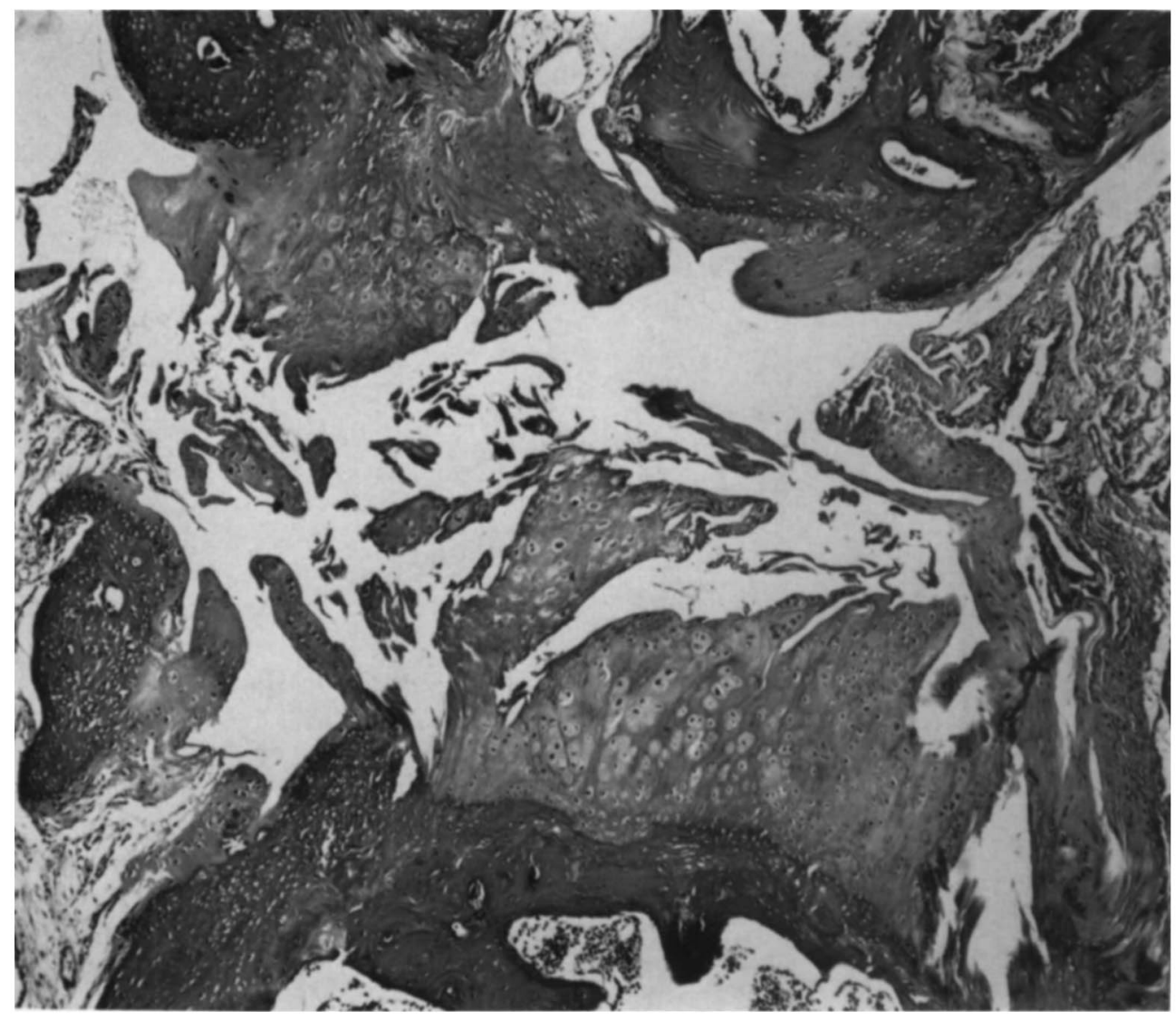

Fig. 3 Osteoarthrosis: Massive cartilaginous outgrowth with extensive fraying at femur (top) and tibia (bottom). $\times 70$. 


\section{Discussion}

With the passing of time the articular tissues undergo a spectrum of alterations progressing from simple age changes to osteoarthrotic lesions. Since the former represent intermediate stages between normal and arthrotic joints, their incidence is meaningless unless considered in relation to both the number of unaffected and diseased joints, respectively. An acceleration and intensification of these processes may be expressed as a "shift to the right," and a delay or attenuation as a "shift to the left." In the present experiments, old age changes were about equally frequent in untreated controls and in non-injected and injected castrates. (53\%, and $55 \%$, and $58 \%$ of the animals, respectively). On the other hand, $8 \%$ of the injected castrates and $41 \%$ of the non-injected castrates had unchanged joints. Osteroarthrosis was noted in $34 \%$ of the castrates which received the steroid, while only one mouse $(4 \%)$ of the non-injected castrates had a low-grade osteoarthrotic lesion.

Progesterone thus partly counteracted the age-retarding effect of castration on the joints, which suggests a growth-promoting action of the hormone on the joints of the castrate mouse. It therefore compensated to some extent for the absence of male sex hormone. The articular effects of prolonged administration of progesterone were thus comparable with those exerted on the epiphyseal cartilage by treatment restricted to the growth period (Silberberg \& Silberberg, 1965).

The mechanism of action of the hormone in these two sets of experiments may also be similar, although the nature of the action is unknown. It has been suggested that progesterone may act on food intake through a central mechanism (Hervey \& Hervey, 1964). However, it is likely that the hormone acts directly on mesenchymal tissue as do other steroids (Silberberg \& Silberberg, 1956).

Progesterone has been previously observed to promote skeletal growth and development. Rat fetuses grew larger than ordinarily, if their mothers were treated with progesterone during pregnancy (Saunders \& Elton, 1959), and in female infants of mothers treated with progestins during pregnancy, not only masculinization but also advanced skeletal maturation was noted (Breibart, Bongiovanni, \& Eberlein, 1963). In the present series of experiments, progesterone slightly increased body weight com. pared with that of non-injected castrates. Female rats given progesterone consumed more food and gained more weight than untreated controls. No such effect was noted in male rats receiving the steroid (Hervey \& Hervey, 1964). This points to a role of the testicles in the different weight response of male and female rats, respectively, to injected progesterone.

On the other hand, progesterone exerted protein-catabolic effects in humans (Landau, Lugibihl, \& Dimick, 1958; Landau \& Lugibihl, 1963) and retarded skeletal development in growing non-castrated mice (Silberberg \& Silberberg, 1965). Little is known about factors that determine the effects of progesterone in a given instance. In females the action of the steroid varied with the titer of circulating estrogen (Lynn \& Brown, 1958; Zarrow, 1961). The hormone is quickly metabolized and readily converted into other steroids (Brush, 1963; Sulman \& Danon, 1963; Okada, Amatsu, Ishihara, \& Tokuda, 1964). Orchiectomy apparently creates conditions enabling progesterone or one of its derivatives to promote growth and aging of cartilage and thus the evolution of osteoarthrosis.

\section{Summary}

Administration of progesterone to orchiectomized mice of strain C57BL Jax6 from youth to old age advanced articular aging and promoted the development of senile osteoarthrosis. The steroid thus counteracted the effect of castration which delayed and attenuated these changes. Whether these effects are exerted by the steroid itself or by one or more of its derivatives, and whether this action on the cartilage is a direct one or involves general metabolic pathways, is unknown.

\section{REFERENCES}

Bennett, G. A., H. Waine, and W. Bauer: Changes in the knee joint at various ages. With particular reference to the nature and development of degenerative joint disease. The Commonwealth Fund, Harvard Univ. Press, Cambridge, 1942, 97 pp.

Breibart, S., A. M. Bongiovanni, and W. R. Eberlein: Progestins and skeletal maturation. New Engl. J. Med., 268: 255-256, 1963.

Brush, M. G.: The metabolism of injected progesterone in the ewe. J. Endocr., 26:65-73, 1963.

Buffett, R. F., and L. C. Wyman: Changes in the region of the tibial epiphyseal cartilage of the rat following adrenalectomy and gonadectomy. Anat. Rec., 125: 17-39, 1956. 
de Palma, A. F.: Degenerative changes in the sternoclavicular and acromoclavicular joints in various decades. Charles C Thomas, Springfield, Ill., 1957, 178 pp.

Geller, J.: The effect of 12-ethyl-19-nortestosterone and 17-ethyl-nortestosterone 3-enol-propionate on growth and endocrine function in normal young males of short stature. Acta endocrinol., 45: 13-25, 1964.

Hervey, G. R., and E. Hervey: Effects of progesterone on food intake and body composition in rats. $J$. Endocr., 30: Proceed. VII-VIII, 1964.

Howard, E.: Effects of steroids on epiphysiodiaphyseal union in prepuberal mice. Endocrinology, 72:11-18, 1963.

Joss, E. E., K. A. Zuppinger, and E. H. Sobel: Effect of testosterone propionate and methyltestosterone on growth and skeletal maturation in rats. Endocrinol ogy, 72: 123-130, 1963.

Landau, R. L., K. Lugibihl, and D. F. Dimick: Metabolic effects in man of sternoids with progestational activity. Ann. N. Y. Acad. Sci., 71: 588-598, 1958.

Landau, R. L., and K. Lugibihl: Influence of progesterone on amino-acid utilization. J. Lab. clin. Med. 62: 991-992, 1963.

Lynn, W. S., Jr., and R. H. Brown: The conversion of progesterone to androgens by testes. J. biol. Chem., 232: 1015-1030, 1958 .

Mainland, D.: Comparison of samples of frequency data. Chapter 12 in: Elementary Medical Statistics. W. B. Saunders \& Co. Philadelphia, 1963, 2nd. Ed., pp. 218-240.

Okada, H., M. Amatsu, S. Ishahara, and G. Tokuda: Conversion of some synthetic progestins to oestrogens. Acta endocrinol., 46:31-36, 1964.

Papadia, L., M. Montinari, and R. Cagnazzo: Sulle modificazioni indotte de alti dosi testosterone sulla cartilagine di incrostazione di ratti in acrescimento. Minerva ortop., Torino, 10:652-659, 1959.

Rönning, O., E. Mäkinen, K. Lathimer, and E. Raijola:
Effect of nandrolone phenylpropionate on the bone of young rats. Endocrinology, 75: 477-482, 1964.

Saunders, F. J., and B. L. Elton: Progestational action of some newer steroids with special reference to maintenance of pregnancy. In: C. W. Lloyd (Editor), Recent Progress in the Endocrinology of Reproduction. Academic Press, New York, 1956, pp. 227-254.

Silberberg, M., and R. Silberberg: Age changes of bones and joints in various strains of mice. Amer. J. Anat., 68:69-95, 1941.

Silberberg, M., and R. Silberberg: Steroid hormones and bones. Chap. 20 in: G. H. Bourne (Editor), The Biochemistry and Physiology of Bone. Academic Press, New York, 1956, pp. 623-670.

Silberberg, M., and R. Silberberg: Ageing changes in cartilage and bone. Chap. 8 in: G. H. Bourne (Editor), Structural Aspects of Ageing. Pitman Med. Publ. Co., London, 1961, pp. 85-108. (a)

Silberberg, R., and M. Silberberg: Male sex hormone and osteoarthrosis in mice. J. Bone Jt. Surg., 43A: 243-248, 1961 (b)

Silberberg, R., and M. Silberberg: Action of progesterone on endochondral ossification of mice. Exp. Med. Surg., 1965 (in press).

Silberberg, R., R. Thomasson, and M. Silberberg: Degenerative joint disease in castrate mice. II. Effect of orchiectomy at various ages. Arch. Path., Chicago, 65: 442-444, 1958

Sulman, F. G., and A. Danon: The mechanism of the "push and pull" principle. VI. Effect of progestogenic hormones on the endocrine system. Arch. int. Pharmacodyn., 141:271-286, 1963.

Weichselbaum, A.: Die senilen Veränderungen der Gelenke und deren Zusammenhang mit der Arthritis deformans. Sitzungsber. d. K. Akad. d. Wissenschaft. 75: 193-243, 1877.

Zarrow, M. X.: Gestation. In: W. C. Young (Editor), Sex and Internal Secretions. Williams \& Wilkins, Baltimore, 1961, 3rd. Ed. Vol. II, pp. 958-1031. 